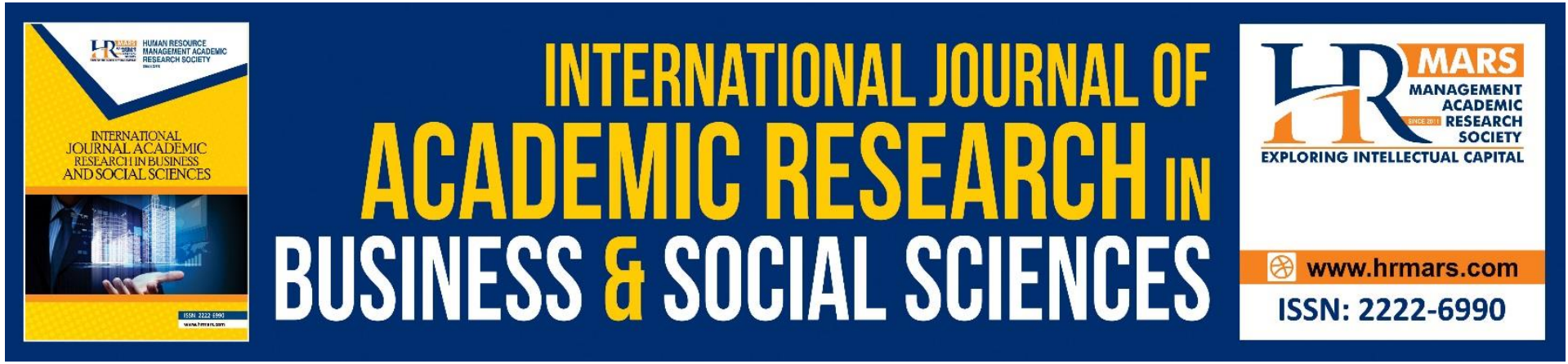

\title{
Using English Vlog within YouTube as A Tool to Enhance Speaking Skills
}

Aminabibi Saidalvi, Amira Mohamad, Wan Farah Wani Wan Fakhruddin

To Link this Article: http://dx.doi.org/10.6007/IJARBSS/v11-i8/10665

DOI:10.6007/IJARBSS/v11-i8/10665

Received: 10 June 2021, Revised: 12 July 2021, Accepted: 03 August 2021

Published Online: 24 August 2021

In-Text Citation: (Saidalvi et al., 2021)

To Cite this Article: Saidalvi, A., Mohamad, A., \& Fakhruddin, W. F. W. W. (2021). Using English Vlog within YouTube as A Tool to Enhance Speaking Skills. International Journal of Academic Research in Business and Social Sciences, 11(8), 1303-1311.

Copyright: (c) 2021 The Author(s)

Published by Human Resource Management Academic Research Society (www.hrmars.com)

This article is published under the Creative Commons Attribution (CC BY 4.0) license. Anyone may reproduce, distribute, translate and create derivative works of this article (for both commercial and non-commercial purposes), subject to full attribution to the original publication and authors. The full terms of this license may be seen at: http://creativecommons.org/licences/by/4.0/legalcode

Vol. 11, No. 8, 2021, Pg. 1303 - 1311

http://hrmars.com/index.php/pages/detail/IJARBSS

JOURNAL HOMEPAGE

Full Terms \& Conditions of access and use can be found at http://hrmars.com/index.php/pages/detail/publication-ethics 


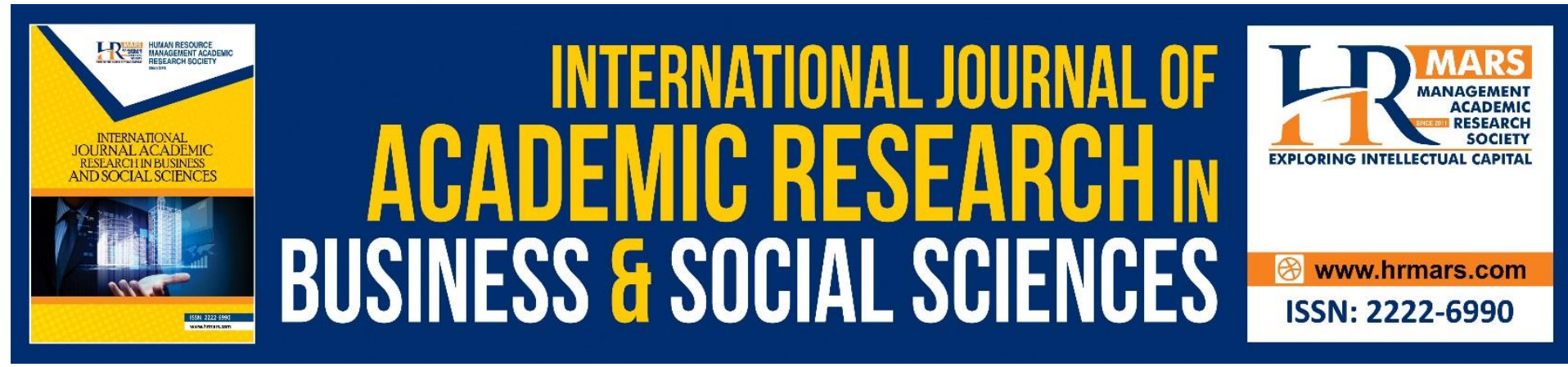

\title{
Using English Vlog within YouTube as A Tool to Enhance Speaking Skills
}

\author{
Aminabibi Saidalvi ${ }^{1}$, Amira Mohamad ${ }^{2}$, Wan Farah Wani Wan \\ Fakhruddin ${ }^{3}$ \\ ${ }^{1}$ Universiti Teknologi MARA, Cawangan Johor, Kampus Pasir Gudang, Malaysia \\ 2,3Universiti Teknologi Malaysia, Skudai, Johor, Malaysia \\ Email: aminabibi@uitm.edu.my¹, mimiamiramohd@gmail.com², wanfarah@utm.my³
}

\begin{abstract}
The objective of this study is to explore students' perceptions of English vlog within YouTube as a tool to improve speaking skills. Participants of this study are 59 fourth-year undergraduate students from a university in Malaysia. The descriptive quantitative research design was employed in this study. Students' perceptions of using English vlog within YouTube to help improve speaking skills were revealed through a questionnaire. There were 4 sections and 30 survey questions. Findings reveal that English Vlog within YouTube offers many positive changes towards students' speaking skills in the aspects of language learning and motivation. Students learn many new vocabularies, proper pronunciation, contextual words, and different slangs besides the increase in motivation to speak in English. Thus, it is encouraged that teachers use English Vlog with YouTube more frequently to enhance students' speaking skills. Furthermore, language programme developers and institutions of higher learning may consider using this technology to improve English speaking skills.
\end{abstract}

Keywords: Video Blog (Vlog), YouTube, Speaking Skills, Speaking, ESL

Contribution/ Originality: This paper's main contribution is the findings that with the aid of technology can enhance speaking skills of students. In this study English vlog within YouTube is the technological tool that was utilised. Students perceived that they learnt new vocabulary, correct pronunciation, accurate contextual words and different slangs of speakers. Students also enhanced self-motivation to speak in English Language.

\section{Introduction}

Vlogging has grown in popularity among all generations as one of the most popular daily digital videos. It is a mix of the words "video" and "blog" that allows users to create, upload, and watch lifestyle videos. Users can record their ideas on a variety of topics and publish them to vlogs using video (Anil, 2016). Review and unboxing products, pranks and comedies, beauty and fashion, tutorials on how to do particular things, lifestyle, gamer, movie and book reviews, travel, pop culture and gossips, and click baits are all popular vlogs among teenagers (Sam, 2019). 
According to Rakhmanina and Kusumaningrum (2017), blogs play a significant role in fostering interaction between students and teachers in the target language. Blogging aids in the development of pupils' speaking abilities. Videoblogging incorporates movies, sound, still photos, and text, it provides a fuller Web experience than traditional text blogging, boosting the amount of information-and potentially emotions-shared with visitors. Most people that have vlogs talk about a variety of things, such as hobbies, tips, short speeches, and so on. This is one of the reasons why vlogs are frequently referred to as online diaries. If a blog is a written piece of information shared on a website, a vlog is a creative video that anybody may make and edit as creatively as they like (adding photos, text, and sounds), then publish or share on social media platforms such as YouTube, Facebook, and others (Fiddan \& Debbag, 2018).

YouTube, is a video-sharing website in which people who create videos are included as users, allowing them to socialise by interacting with other users (Burgess \& Green 2009), allowing voting and comments (Chang \& Lewis, 2011), and allowing followers to be more involved in the lives of the users (Stever \& Lawson, 2013). It is one of the social media platforms that can be accessed widely to upload and view vlogs from various countries with a variety of knowledge contents (Clarkson, 2015). YouTube is the website that hosts the highest number video blogs (35\%) in comparison with the other video sharing sites (Mogallapu, 2011). It is a useful platform for students to learn second language skills because it can be integrated with various form of lesson planning both inside and outside of the classroom (Jalaluddin, 2016). Students are familiar to watching videos for their classes and schoolwork in the universities. According to Kahler, Jacobs, Raftery, and Ditnes (2017), 68 percent of students report seeing YouTube videos for class lessons and assignments.

Besides, there are four main skills that ESL students need to master in English language learning. One of them is speaking. The ability to speak and communicate well becomes important language learning skills. The essential elements of speaking skill that need to be mastered by students include vocabulary, grammar, pronunciation, content, and fluency. Vocabulary is important to deliver ideas and information with the aid of good grammar. Good grammar helps students to develop correct structure of English. Next is correct pronunciation that help students to produce good sounds and English voice which leads to better interpretation of messages. Content provides focus for delivering and lastly fluency is important to help students in matter related to production of spoken language (Bandasari \& Aminatun, 2019).

Vlog comes with the goal of giving a tool to help students learn English more easily, particularly in terms of speaking ability. Vlog is able to assist them in improving their English speaking skills. In earlier studies, Sari (2018) discovered that the majority of students believed that vlogging helps them gain confidence in speaking English and allow them to communicate freely and confidently. Video blogging has a positive impact on students' oral skills development (Santamaria et al., 2018) by utilising digital technologies such as video cameras (Combe and Codreanu, 2016), and they allow students to express themselves and engage in more public speaking activities with audiences (Sulistyo, 2018). This research is significant since it looked into students' perspectives of the use of English vlogs within YouTube to enhance their speaking skills. The outcomes of this study is useful to educators in varying their 
ESL activities, particularly speaking tasks, by incorporating English vlogs. within YouTube when teaching.

The main research question of the study is 'What are the students' perceptions on the use of English vlog within YouTube in enhancing speaking skills?'.

\section{Methodology}

59 Fourth-year undergraduate students participated in this quantitative study carried out in a public university in Malaysia. The respondents were selected using random sampling technique. Besides, the table of sample size by Krejcie and Morgan's (1970) was used to set the sample size from the whole population.

A set of questionnaire with 4 points Likert scale was utilised to collect data in this study. According to Bertram (2013), a Likert scale is an ordered scale from which respondents choose one option that best aligns with their view. It is useful in measuring respondents' perceptions by asking the extent to which they agree or disagree with a particular question or statement. The questionnaire was adapted from Safitri and Khoriyah (2017) and Balbay and Kilis (2017). The former conducted research on students' perceptions on the use of English vlog to enhance speaking skills and the latter studied students' perceptions of the use of a YouTube channel specifically designed for an academic presentations skills course.

The questionnaire consisted of 30 items which include four sections. Section $A$ is demographical information. Section B on types of English vlog on YouTube; Section C investigating the frequency of watching English vlog on YouTube and Section D on students' perception on the use of English vlog within YouTube to enhance speaking skills. SPSS analysis of the instrument reveals a Cronbach alpha of .943 thus showing the reliability of the instrument (Glen, 2021).

Data was collected via goggle form and analysed using SPSS version 25. Findings is presented in the form of descriptive analysis showing percentages and mean scores.

\section{Findings and Discussions}

This section provides findings on demographic information, the perceptions of students regarding using English vlog within YouTube in learning. The findings provide answers to the research question. 


\subsection{Demographic Information}

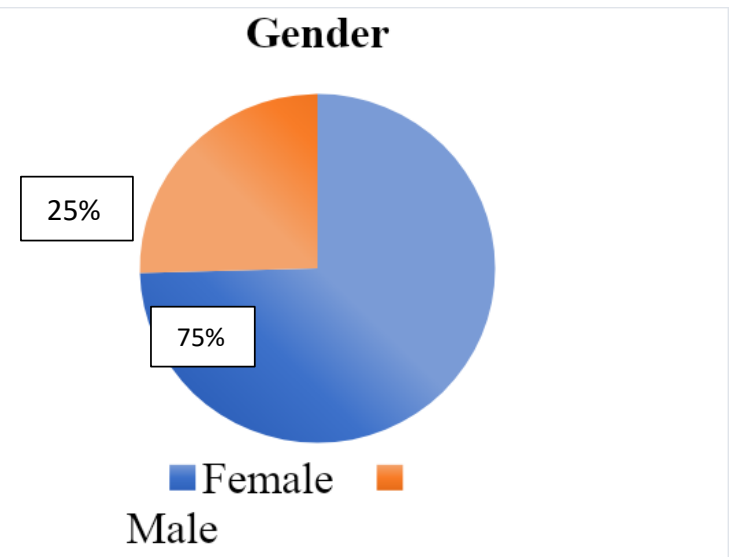

Figure 1: Gender of the respondents

Figure 1 shows the percentage of the gender distribution among the respondents of the study. The data indicates that female respondents are more than male respondents. They made up 75 percent $(n=44)$ of the respondents whereas only 25 percent $(n=15)$ male respondents. participated in answering the survey.

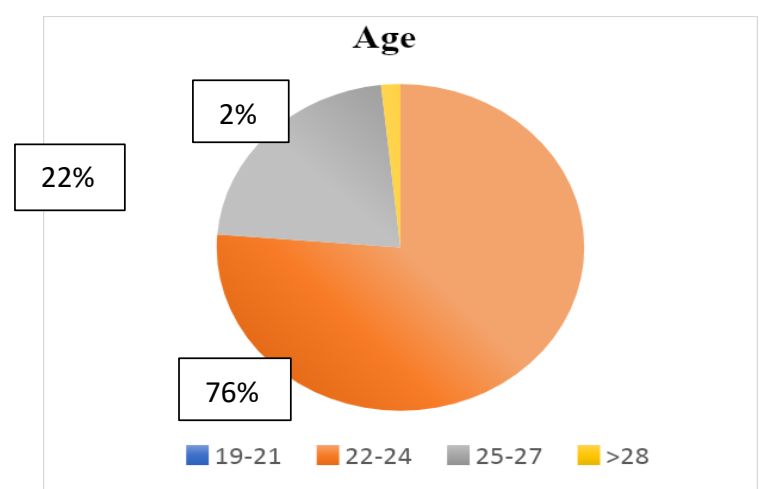

Figure 2: Age group of the respondents

Figure 2 highlights the proportion of the respondents' age. The number of students age 2224 is 45 respondents (76\%). Meanwhile, there are 13 respondents age from 25-27 (22\%) and age 28 with only one student (2\%). There are also none from the $19-21$ age group. 


\subsection{Types of English vlog within YouTube topics preference}

Figure 3 presents the types of English vlog topic within YouTube preferred by the respondents.

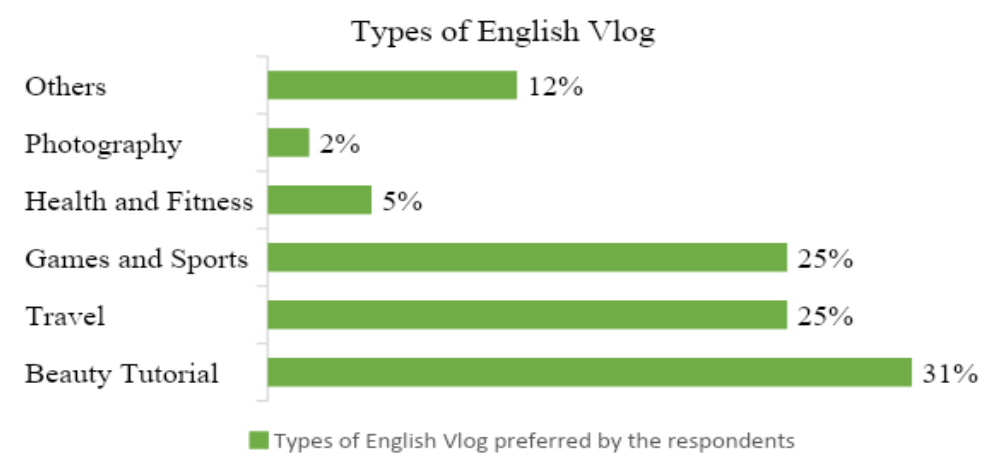

Figure3: Types of English vlog within YouTube preference

Based on the Figure 3, there are five English vlog within YouTube preferred by students. Among others are photography, health and fitness, games and sports, travel and beauty tutorial vlog. The most preferred English vlog by the respondents with the highest percentage which is 31percent is beauty tutorials. This might be due to the respondents consists of mostly female (Figure 1). This followed by games and sports English vlog and travel that share the same percentage of 25 percent respectively. Next, English vlog preference is health and fitness which comprises 5 percent while photography is 2 percent. Respondents have also preferred other English vlogs within YouTube such as entertainment, educational, daily life, business, horror, facts, and music review which accumulates to 12 percent.

\subsection{Using English Vlog Within YouTube Towards Students' English Learning}

Table 1 indicates the findings of using English vlog within YouTube towards students' English learning based on the students' perceptions.

Table 1: Using English vlog towards students' English learning

\begin{tabular}{|l|c|c|c|c|}
\hline \multicolumn{1}{|c|}{ Items } & $\begin{array}{c}\text { Strongly } \\
\text { agree }\end{array}$ & Agree & Disagree & $\begin{array}{c}\text { Strongly } \\
\text { disagree }\end{array}$ \\
\hline I learn many new English words. & $\begin{array}{c}24 \\
(41 \%)\end{array}$ & $\begin{array}{c}34 \\
(58 \%)\end{array}$ & $\begin{array}{c}1 \\
(2 \%)\end{array}$ & $\begin{array}{c}0 \\
(0 \%)\end{array}$ \\
\hline I am able to know new English terms in & 27 & 32 & 0 & 0 \\
certain context. & $(46 \%)$ & $(54 \%)$ & $(0 \%)$ & $(0 \%)$ \\
\hline I learn how to pronounce English words & 19 & 39 & 1 & 0 \\
correctly. & $(32 \%)$ & $(66 \%)$ & $(2 \%)$ & $(0 \%)$ \\
\hline I learn variety English accents from the & 24 & 32 & 3 & 0 \\
native speakers. & $(41 \%)$ & $(54 \%)$ & $(5 \%)$ & $(0 \%)$ \\
\hline I learn the correct English grammar use. & 12 & 37 & 10 & 0 \\
& $(20 \%)$ & $(63 \%)$ & $(17 \%)$ & $(0 \%)$ \\
\hline I discover many English slangs. & 26 & 28 & 5 & 0 \\
& $(44 \%)$ & $(47 \%)$ & $(8 \%)$ & $(0 \%)$ \\
\hline
\end{tabular}


Table 1 clearly highlights that the majority of the students have positive perceptions regarding the use of English vlog within YouTube to learn speaking skills. This can be seen from Table 1 that none were found to strongly disagree to the items given. There is only 34 percent of the respondents disagreed to the item given. It is interesting to note that all the students agreed that they are able to know new English words used in context. Besides, the respondents also agreed that they learn new English words. A total of 41 percent strongly agreed and 58 percent agreed they learnt new English words. Additionally, it was discovered that the respondents learnt English accents from the native speakers and also various English slangs with strongly agree of 41 percent and 44 percent respectively. This result is supported by a research conducted by Safitri and Khoiriyah (2017) and Chottsawhas (2016) which they found that watching English vlog helps students to enrich the vocabulary, learn new form of words from different context and encourage students to understand many terms used across the culture. Riswandi (2016) in a study found that YouTube based videos using English vlog really help students in developing new English vocabulary and they relate ideas to the content of what to speak.

\subsection{Using English vlog within YouTube enhances motivation of students}

Figure 3 presents the results of students' perceptions in the aspects of motivation.

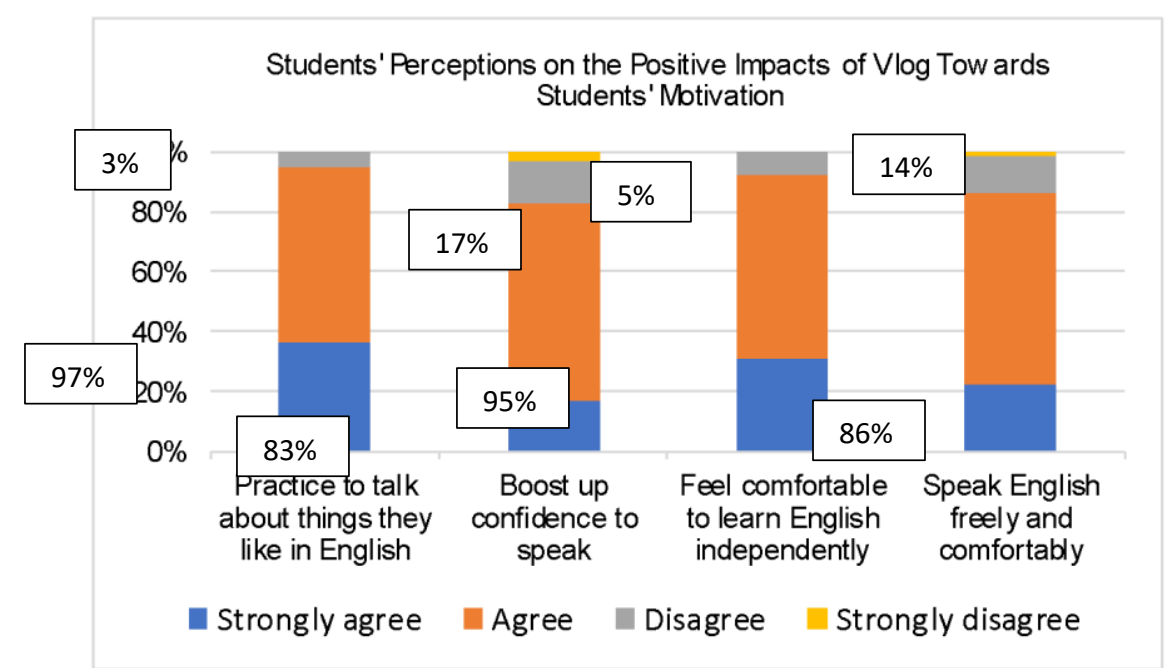

Figure 3: Using English Vlog within YouTube and students' motivations

Data analysis discovered that students have positive motivation when using vlog within YouTube. Figure 3 depicts the result the four main items asked in the questionnaire. As shown in Figure 3, it was noted that only a small percentage of students disagreed that they gain motivation when using vlog within YouTube. 97 percent $(n=57)$ of the respondents agreed and strongly agreed that they can practice speaking in English about things they like by vlogging and only 3 percent disagreed. Similarly, 95 percent $(n=56)$ students agreed that they feel comfortable to learn English independently using English vlog within YouTube. Although it can be seen that 17 percent of the respondents disagreed that using English vlog within YouTube boost speaking confidence, 83 percent $(n=49)$ have positive perception. It can be noted that students feel their motivation to speak in English is uplifted and the English vlog within YouTube provides this positive atmosphere to learn speaking English. 
The findings corroborates with findings by Gao et al. (2010) where it was discovered in their research students can practice speaking freely about things they like as the concept of vlog is to talk and share any content that the speaker want to share without any specific style or format. In addition, Rahmawati et al., (2018) shared the same point when they discovered students become more interested, confident and enjoyed speaking English using English vlog although they were not familiar with it at the beginning. A recent study conducted by Syafiq et al. (2021, p. 50) showed that "YouTube video as English learning material improved speaking skill of students including fluency, vocabulary, pronunciation, grammar, and content." This as well is in agreement with the findings of this piece of research. The results reported by Jati et al. (2019, p. 101) showed that the students' speaking skill was improving in three aspects; firstly accuracy, secondly fluency, and thirdly performance. Similar findings on the effectiveness of vlog and YouTube videos in improving students' speaking skills were reported by many studies in the literature (Albahlal, 2019; Arroyyani, 2018; Pratama et al., 2020; Setiawan and Wiedarti, 2020; Tristiana and Swondo, 2020).

\section{Conclusion}

This study investigated the usage of English vlog within YouTube as a tool to enhance students' speaking skills from the students' perceptions. Speaking skills can be strengthened and improved with the help of technology. English Vlog within YouTube are technical instruments that provide ESL learners with numerous benefits.

Based on the findings of the study, students have positive perceptions of using English vlog within YouTube to develop speaking. They are positive that English vlog within YouTube help in learning many new vocabularies, proper pronunciation, correct contextual words, and different slangs. Besides, it was perceived to increase students motivation to speak in English. The participants see that it is easy to learn English speaking skills using English vlog within YouTube as they feel comfortable and free to speak on topics of interest. This is in line with a recent study conducted by Syafiq et al. (2021, p. 50) that highlighted YouTube video as English learning material improved speaking skill of students including fluency, vocabulary, pronunciation, grammar, and content. This as well is in agreement with the findings of this research.

English vlog within YouTube is a new method that emphasises the interactive nature of speaking. It contains a number of features that help students move from dependent to independent learners. Features like allowing students to freely choose topics of interest and independently completing assigned tasks and learning new vocabulary encourages students self-motivation. Students can practice speaking skills by watching English vlog that are appropriate for them. Thus, eventually enhances speaking skills.

The findings of the study can help curriculum designers to consider students' latest interest in technology specifically English vlog within YouTube. Learning related to students' interest and current needs boost self-motivation and enhances speaking skills. Language programme developers and universities may consider improving programmes, courses, teaching aids or seminars that is related to speaking skills. 


\section{References}

Anil, B. (2016). Top-Up Students Second Language Talk Time through Vlogs. Indonesian Journal of EFL And Linguistics, 1(2).

Chottsawhas, P. (2016). English Language Users' Perceptions Towards the Use of Vlogging As an English Speaking Activity. Thammasat University 2016.

Clarkson, S. (2015). Vlog it! (p. 11). London: Scholastic Ltd.

Gao, W., Tian, Y., Huang, T., \& Yang, Q. (2010). Vlogging: A survey of videoblogging technology on the web. ACM Computing Surveys, 42(4). https://doi.org/10.1145/1749603.1749606

Jalaluddin, M. (2016). Using YouTube to Enhance Speaking Skills in ESL Classroom. English For Specific Purposes World, 17(50).

Krejcie, R. V., \& Morgan, D. W. (1970). Determining Sample Size for Research Activities. Educational and Psychological Measurement, 30, 607-610.

Rahmawati, A., Harmanto, B., \& Indriastuti, N. R. (2018). The Use of Vlogging To Improve the Students' Speaking Skill. Edupedia, 2(1), 87. https://doi.org/10.24269/ed.v2i1.96

Rakhmanina, L., \& Kusumaningrum, D. (2017). The Effectiveness of Video Blogging in Teaching Speaking Viewed from Students' learning Motivation. Proceedings of ISELT FBS Universitas Negeri Padang, 5, 27-34.

Riswandi, D. (2016). Use of YouTube-Based Videos to Improve Students' Speaking Skill. The 2nd International Conference on Teacher Training and Education Sebelas Maret University, 2(1), 298-306.

Safitri, N., \& Khoiriyah, I. (2017). Students' Perceptions on the Use of English Vlog (Video Blog) to Enhance Speaking Skill. In ASEAN/Asian Academic Society International Conference Proceeding Series (Vol. 5, No. 1, pp. 240-247).

Sam. (2019). VlogLikePro.com - Self Claimed \#1 Source for Learning How to Vlog!. Retrieved 1 November 2019, from http://vloglikepro.com/

Santamaria, C. F., Carlos, A. M. F., \& Encalada, E. G. (2018). The Relationship between the Use of Video Blogging and the Development of Speaking Skills: A Preliminary Study. 2018 5th International Conference on EDemocracy and EGovernment, ICEDEG 2018, 375-379. https://doi.org/10.1109/ICEDEG.2018.8372311

Sari, P. (2018). Using Vlog in the Youtube Channel as a Means To Improve Students' Motivation And Confidence to Speak English in Intermediate 1 Level of LB-LIA Jambi. International Journal of Language Teaching and Education, 1(1), 38-44. https://doi.org/10.22437/ijolte.v1i1.4596

Sulistyo, P. B. (2018). Teenagers Preferences, Creations and Participation in Vlogging Activities. International Journal of Scientific and Research Publications (IJSRP), 8(8). https://doi.org/10.29322/ijsrp.8.8.2018.p80113 